\title{
Audit, Accounting, and Finance Training for Management Trainees of PT HSBC Jakarta
}

\author{
Wiwiek Mardawiyah Daryanto ${ }^{1 *}$ \\ ${ }^{1}$ Sekolah Tinggi Manajemen IPMI, Jakarta Selatan, Indonesia \\ wiwiek.daryanto@ipmi.ac.id
}

(Received April 26, 2021, accepted October 28, 2021)

\begin{abstract}
Accounting is an information service related to all of the activities in the organization, such as operating activities, financing activities, and investing activities. And in all of the activities the emphasis is on using accounting information in the process of making decisions based on financial reports. The financial reports are the result of the accounting process. One related discipline is auditing, which can be defined as the process of examining and evaluating a company's financial statements through an independent auditor. In addition, accounting is used to support the management for internal decision making, or called management accounting. To understand the importance of accounting, Sekolah Bisnis dan ManajemenInstitut Teknologi Bandung (SBM-ITB) in collaboration with PT HSBC, Jakarta, Indonesia conducted General Banking Training on March 22-26, 2021. The training consists of nine (9) topics, including Auditing, Accounting and Finance and is held on March 23, 2021. The speakers of the training are several academicians, including the author. The method used in the training is online lecturing and discussion combined with case studies. We also conducted pre and post-tests to ensure the result of the training. The participants are seven (7) new employees of PT HSBC recruited from various domestic and foreign universities. The results of the training showed that the participants improved their understanding on the importance and the use of accounting information based on pre and posttests. In addition, it showed an increase in value of $54 \%$ in the posttest. Further, the participants are satisfied and provide positive feedback of 4.14 out of 5. After observing the process, we consider that the training ran smoothly and effectively due to high interest and enthusiasm of the participants.
\end{abstract}

Keywords: audit; accounting; financing; PT HSBC 


\section{Introduction}

Accounting is the language of business used by manager to communicate his/her business thoughts to his/her subordinates and outsiders (Anthony et. al, 2011). From the financial statements produced by the accounting system, a company can assess its ability to fulfills its short-term obligations, the company's capital structure, the distribution of assets, the effectiveness of use of assets, results of operations or income that have been achieved, expenses to be paid, and the book values of each share of the company concerned.

One discipline knowledge related to accounting, namely auditing. Auditing is a a process carried out by an independent examiner to examine the financial statements of a company to provide an opinion or an objective opinion, whether the company's financial statements are prepared based on common accounting principles and assess the reasonableness of the contents of the financial statements (Anthony et. al, 2011). Aside of understanding the financial statement information and auditing, classification of costs in cost accounting is also essential for management to learn and implement in supporting the company's success.

Given the great benefits of accounting information, Sekolah Binis dan Manajemen-Institut Teknologi Bandung (SBM-ITB) in collaboration with PT HSBC, Jakarta, Indonesia conducted a general banking Training on 22-26 March 2021. PT HSBC is one of the largest banking groups in the world with many branches in Jakarta. Out of the nine (9) subject matters contained in the program, one of them is Audit, Accounting, and Finance Training which is scheduled for March 23, 2021 with the author as one of the speakers. The author's appointment letter as one of the speakers at the training can be seen in Figure 1.

The participants in the Audit, Accounting and Finance training were seven new employees of PT HSBC recruited from various universities at home and abroad. A list of names and educational backgrounds, as well as the participating universities' origin can be seen in Table 1. 
YAYASAN SANGGA BUWANA MAHARDIKA (SBM)

School of Business \& Management ITB

TK Low Center for Executive Education

Graha Irama $12^{\text {th }} \mathrm{fl}$.

Jl. HR Rasuna Said Kav. 1-2, Jakarta 12950

Indonesia

No : 02/SR/SBM/Yayasan/03/2021

$\mathrm{Re} \quad$ : Facilitator HSBC General Banking Training

Dear,

Dr. Wiwiek Mardawiyah Daryanto

Lecturer Sekolah Tinggi Manajemen IPMI

It is a great pleasure to write to you regarding my intention to invite you as a speaker for the HSBC General Banking Training. The sessions will be hosted by the School of Business and Management ITB.

The details of your proposed dialogue session are as below:

Tuesday, 23 March 2021

\begin{tabular}{|c|c|c|c|c|c|c|}
\hline \multirow{2}{*}{ Session } & \multirow{2}{*}{ Topic } & \multirow{2}{*}{ Facilitator } & \multirow{2}{*}{$\begin{array}{l}\text { Pre I } \\
\text { Post } \\
\text { Test } \\
\end{array}$} & \multicolumn{2}{|c|}{ Time } & \multirow{2}{*}{ Duration } \\
\hline & & & & Start & Finish & \\
\hline \multirow[t]{2}{*}{1} & Audit, Accounting \& Finance & $\begin{array}{l}\text { Dr. Wiwiek } \\
\text { M. Daryanto }\end{array}$ & Yes & 9:00 & $10: 30$ & $1: 30$ \\
\hline & Coffee Break 1 & & & $10: 30$ & $10: 45$ & $0: 15$ \\
\hline \multirow[t]{2}{*}{2} & Audit, Accounting \& Finance & $\begin{array}{l}\text { Dr. Wiwiek } \\
\text { M. Daryanto }\end{array}$ & & $10: 45$ & $12: 15$ & $1: 30$ \\
\hline & Lunch \& Prayer & & & $12: 15$ & $13: 15$ & $1: 00$ \\
\hline \multirow[t]{2}{*}{3} & Audit, Accounting \& Finance & $\begin{array}{l}\text { Dr. Wiwiek } \\
\text { M. Daryanto }\end{array}$ & Yes & $13: 15$ & $14: 45$ & $1: 30$ \\
\hline & Coffee Break 2 & & & $14: 45$ & $15: 00$ & $0: 15$ \\
\hline 4 & Audit, Accounting \& Finance & $\begin{array}{l}\text { Dr. Wiwiek } \\
\text { M. Daryanto }\end{array}$ & & $15: 00$ & $16: 30$ & $1: 30$ \\
\hline
\end{tabular}

To discuss more on the program, we are more than welcome to arrange an online meeting and will adjust the exact timing with your preference accordingly. Thank you in advance for your kind and courteous attention, looking forward to hearing good news from you.

Yayasan Sangga Buwana Mahardika,

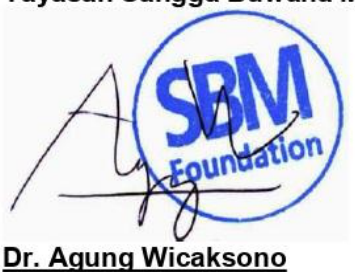

Dr. Agung Wicaksono

Chairman

Fig. 1. Letter of appointment as speaker (source: Sekolah Bisnis dan Manajemen- Institut Teknologi Bandung (SBM-ITB), 2021) 
Table 1. List of participants in audit, accounting, and finance training on March 23, 2021

\begin{tabular}{clllll}
\hline No. & Name & Universities' Origin & Country & Major & Degree Level \\
\hline 1. & $\begin{array}{l}\text { Arum Maharani } \\
\text { Feminingtyas }\end{array}$ & $\begin{array}{l}\text { Sekolah Bisnis dan } \\
\text { Manajemen - ITB }\end{array}$ & Indonesia & Entrepreneurship & Bachelor \\
2. & Gusti Ngurah & $\begin{array}{l}\text { Sekolah Bisnis dan } \\
\text { Manajemen - ITB }\end{array}$ & Indonesia & $\begin{array}{l}\text { Business } \\
\text { Administration }\end{array}$ & Master \\
3. & Marsellino Unggul & Universitas Jember & Indonesia & Information System & Bachelor \\
4. & $\begin{array}{l}\text { Michael Gregory } \\
\text { Budiatmadjadja }\end{array}$ & Universitas Indonesia & Indonesia & $\begin{array}{l}\text { Chemical } \\
\text { Engineering }\end{array}$ & Bachelor \\
5. & Affan Hibaturrahman & $\begin{array}{l}\text { Sekolah Bisnis dan } \\
\text { Manajemen - ITB }\end{array}$ & Indonesia & $\begin{array}{l}\text { Business } \\
\text { Administration }\end{array}$ & Master \\
6. & Dandy Aldilax & Sekolah Bisnis dan & Indonesia & Entrepreneurship & Bachelor \\
7. & Christopher & University of Hong Kong & Hong Kong & $\begin{array}{l}\text { Global Business } \\
\text { Systems }\end{array}$ & Bachelor \\
& & & Management & \\
\hline
\end{tabular}

Source: Sekolah Bisnis dan Manajemen-Institut Teknologi Bandung (SBM-ITB) (2021)

\section{Literature Review}

\section{Financial Accounting}

According to Anthony et. al (2011), as developed by the Committee of the American Accounting Association, accounting is defined as the process of identifying, measuring, and communicating economic information to enable informed judgments and decisions by users of information. Financial accounting includes 3 (three) functions, namely the process of identifying, measuring, and communicating economic information to make it possible for users of accounting information to make estimates and make decisions.

According to Anthony et. al (2011), accounting as a language of business is classified into three groups; operating information, financial accounting information, and management accounting information. The detailed definition are as follows:

1. Operation information

To carry out day-to-day company activities, management requires various operating information such as the amount of raw materials used in the production process, the number of production today, the number of products sold today, and other operating information. This operating information is the raw material for processing other types of accounting 
information, namely financial accounting information, management accounting information, and tax accounting information.

2. Financial accounting information

Financial accounting information is required by both internal and external parties, such as shareholders, bankers and other creditors, government agencies, and other external parties. This financial accounting information is required for outsiders to make decisions in order to determine the relationship between these outsiders and the company. This financial accounting information is produced by a financial information processing system called financial accounting. This financial information is generally presented outside the company in financial statements in the form of balance sheets, income statements, retained earnings reports, cash flow statements, and changes in financial position.

3. Management accounting information

Management accounting information is required by management to carry out two main management functions, namely planning and controlling company activities. Management accounting information is generated by a financial information processing system called management accounting. Management accounting information is presented to company management in various forms of financial reports such as budgets, sales reports, production cost reports, cost reports, and activity cost reports and others according to management's needs. Figure 2. depicts management accounting as one of the types of information.

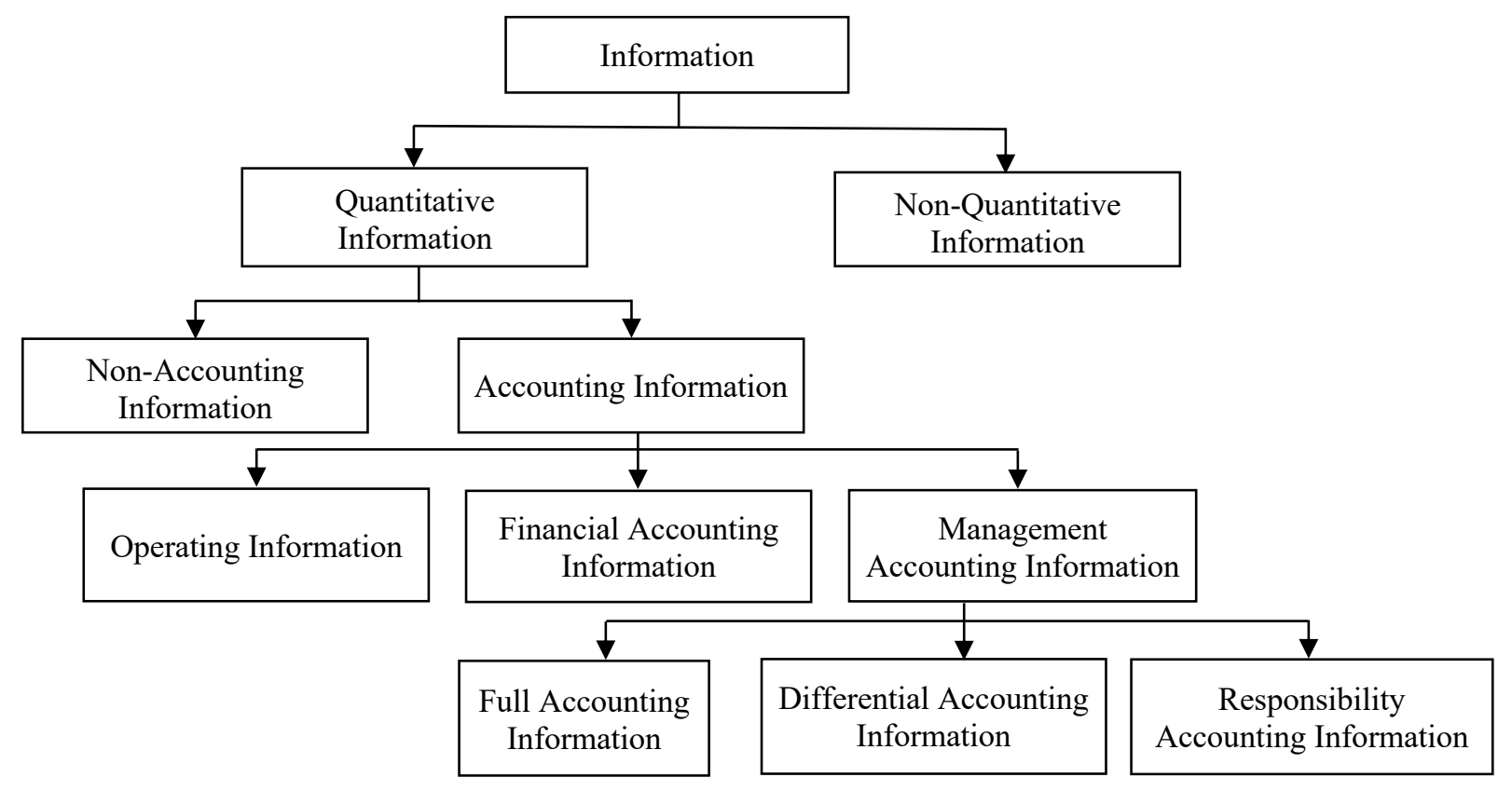

Fig. 2. Management Accounting as One of the Types of Information.

(Source: Anthony et. al, 2011) 
The information generated by financial accounting is common to a wide variety of users. The user groups that typically require financial accounting information are:

1. Company owners/management need this information as a basis for decision making in the company.

2. Creditors/bankers need this information as a decision-making tool whether they will extend the company's credit extension or refuse it.

3. The government uses this information as the basis for determining the amount of taxes, etc.

4. Investors use this information as a basis for making decisions whether they will invest by looking at the company's future prospects.

\section{Financial Statements}

According to Kasmir (2016), financial statements describe the financial condition of a company in a certain period, which is required by interested parties, such as investors, creditors, and management. There are three main types of financial reports, namely, as follows:

\section{Income Statement}

The income statement is a financial report that contains information related to the success of the company in a certain period. The income statement contains information on transactions of income, expenses, gains and losses. The income statement is useful as a determinant of policies in the company to predict future cash flows.

2. Balance Sheet

The balance sheet is part of the financial statements of an entity produced in an accounting period that shows the financial position of the entity at the end of the period, or at a certain time. The balance sheet consists of three elements, namely assets, liabilities, and equity which are related to the following accounting equation:

Asset $=$ Liability + Equity

Information that can be presented on the balance sheet includes, among other things, the position of the source of the entity's assets and the sources of financing to acquire the entity's assets during an accounting period.

3. Cash Flow Statement

The cash flow statement is part of the financial statements of a company produced in an accounting period that shows the inflows and outflows of money (cash) of the company. Cash flow information is useful for assessing the accuracy of the cash flow estimates that have been made previously, as well as being a tool of accountability for cash inflows and cash outflows during the reporting period. Cash flows are grouped into three activities, 
namely operational activities, investing activities, and financing activities or sources of funds.

\section{Management Accounting}

Cost classification is a more concise and systematic process of grouping all components in order to provide more accurate and useful information for decision making (Purwaji et al., 2016). Therefore, there is a concept of classifying certain costs for specific purposes or different cost classification for different purposes.

According to Mulyadi (2010), there are various ways of classifying costs, namely:

1. Classification of Costs According to the Objects of Expenditure.

2. Classification of Costs According to Main Functions in the Company.

3. Classification of Costs According to Cost Relationships with something being Financed.

4. Classification of Costs According to Behavior in Relation to Changes in Activity Volume.

5. Classification of Costs based on their Benefit Period.

Meanwhile, according to Bustami and Nurlela (2010), the classification of costs commonly used is cost in relation to the following:

Costs in relation to products.

1. This cost used in the production process which consists of:
a. Direct raw material costs
b. Direct labor costs
c. Factory overhead costs

2. Costs in relation to the volume or behavior of costs

3. Costs in relation to the production department

Grouping costs in relation to the production department, namely:
a. Cost in relation to time period
b. Cost in relation to decision making

\section{Auditing}

Auditing is an activity of examining and evaluating the records of the results of financial accounting activities which test the feasibility of financial reports and compliance with common accounting principles by independent and objective parties. 
According to Mulyadi (2002) auditing is a systematic process for obtaining and objectively evaluating statements about economic activities and events. Meanwhile, Agoes, S (2004) defines auditing as an examination that is carried out critically and systematically by an independent party, on financial reports that have been prepared by management along with accounting records and supporting evidence, with the aim of being able to provide an opinion regarding the fairness of these financial statements.

\section{Objective of Auditing}

According to Arens et al. (2015), the audit aims to provide an opinion on the appropriateness of financial reporting in accordance with the applicable financial accounting framework. The general audit objectives can be classified as follows:

\section{Completeness}

To ensure that all transactions have been recorded or are actually included in the journal.

\section{Accuracy}

To ensure that transactions and estimated balances are recorded based on the correct amount, the calculation is correct, classified and recorded properly.

3. Existence (Existence)

To ensure that all recorded assets and liabilities have an existence or event on a certain date, the recorded transactions must actually have occurred and are not fictitious.

4. Assessment (Valuation)

To esnure that generally accepted accounting principles have been applied correctly.

\section{Method}

The Audit, Accounting and Finance training was conducted through online classes, due to the Covid 19 pandemic period; and is divided into three (3) stages, namely:

1. Pre-Test Stage. This is done to measure the ability of participants before the training, which took a time for 15 minutes.

2. Training Stage. During the training, the facilitator explained the training materials using the lecturing method and case studies using Powerpoint Tools (PPT). There were also active and dynamic questions and answers session from 09.00 - 16.30 including break. PPT materials had been distributed several days earlier, so that participants read the case studies. Photo evidence of training activities can be seen in Figure 3. 
3. Post-Test Stage. At the end of the training, the facilitator distributed Post-Tests to participants to measure the extent to which participants understand the material presented. The Post-Test took 15 minutes.
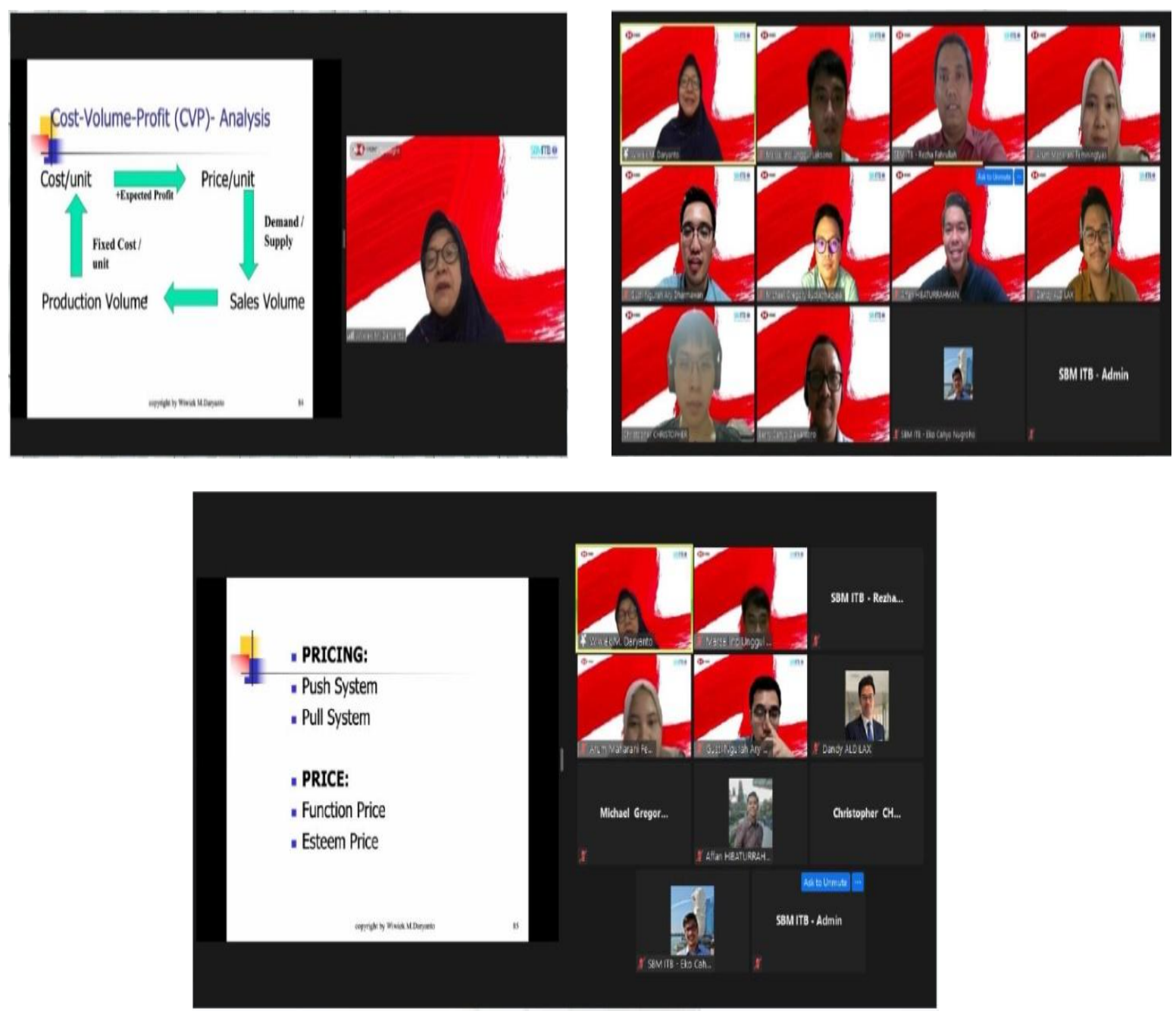

Fig. 3. Photographs of audit, accounting, and finance training activities conducted online through Zoom meetings

(Source: Sekolah Bisnis dan Manajemen-Institut Teknologi Bandung (SBM-ITB), 2021)

\section{Results and Discussions}

Based on the results of the Pre and Post Tests and direct observations, Table 2 reports that the understanding of the participants have increased around 54\% after the training. There are factors that support the implementation of this training, including the great interest and enthusiasm of the participants during the activity, so that the activity runs smoothly and effectively. Besides that, the executive committee has planned this program very well. On the other side, the inhibiting factor is the limited training time. 
Table 2. Participant Pre and Post Test Results on Audit, Accounting, and Finance Training

\begin{tabular}{|c|c|c|c|c|c|}
\hline \multirow[t]{2}{*}{ No } & \multirow[t]{2}{*}{ Name } & \multicolumn{2}{|c|}{$\begin{array}{c}\text { Audit, Accounting \& } \\
\text { Finance }\end{array}$} & \multirow{2}{*}{$\begin{array}{c}\text { Increase in } \\
\text { Value } \\
\text { (number) }\end{array}$} & \multirow{2}{*}{$\begin{array}{c}\text { Increase in } \\
\text { Value } \\
(\%)\end{array}$} \\
\hline & & Pre Test & Post Test & & \\
\hline 1. & Arum Maharani Feminingtyas & 11,144 & 14,711 & 3,567 & $32 \%$ \\
\hline 2. & Gusti Ngurah & 9,383 & 13,035 & 3,652 & $39 \%$ \\
\hline 3. & Marsellino Unggul & 5,577 & 8,528 & 2,951 & $53 \%$ \\
\hline 4. & $\begin{array}{l}\text { Michael Gregory } \\
\text { Budiatmadjadja }\end{array}$ & 10,105 & 12,460 & 2,355 & $23 \%$ \\
\hline 5. & Affan Hibaturrahman & 6,171 & 13,316 & 7,145 & $116 \%$ \\
\hline 6. & Dandy Aldilax & 8,563 & 14,699 & 6,136 & $72 \%$ \\
\hline 7. & Christopher & 7,859 & 11,330 & 3,471 & $44 \%$ \\
\hline \multicolumn{4}{|c|}{ Average } & 4,182 & $54 \%$ \\
\hline
\end{tabular}

Source: Sekolah Bisnis dan Manajemen-Institut Teknologi Bandung (SBM-ITB) (2021)

The participants' evaluation and feedback towards the facilitators also showed an average of 4.14 or in a very good grade; with a scale of 1 (lowest) to 5 (highest). The detailed assessment can be seen in Table 3 .

Table 3. Evaluation and Feedback of Participants to the Facilitator

\begin{tabular}{clc}
\hline No. & Criteria Evaluation & Grade (1-5 scale) \\
\hline 1. & Presentation benefit & 4.50 \\
2. & Structure of lecture content & 4.25 \\
3. & Clarity of explanation and presentation & 3.50 \\
4. & Knowledge on the topic & 4.50 \\
5. & Respond to question & 4.00 \\
6. & Lecture's ability to motivate the participants & 3.75 \\
7. & Discussion environment & 4.50 \\
8. & Level of topic appropriateness & 4.00 \\
9. & Presentation materials & 4.25 \\
10. & Lecturer's questions and cases quality & 4.25 \\
11. & Overall presentation & 4.00 \\
\cline { 2 - 2 } & & Overall rank \\
\cline { 2 - 3 }
\end{tabular}

Source: Sekolah Bisnis dan Manajemen-Institut Teknologi Bandung (SBM-ITB) (2021) 
This evaluation includes an assessment of the presentation benefits, structure of lecture content, clarity of explanation and presentation, knowledge on the topic, respond to questions, lecture's ability to motivate the participants, discussion environment, and level of topic appropriateness, presentation materials, lecturer's questions and cases quality, and overall presentation.

The facilitator also received a certificate as a token of appreciation from the organizers, as shown in Figure 4.

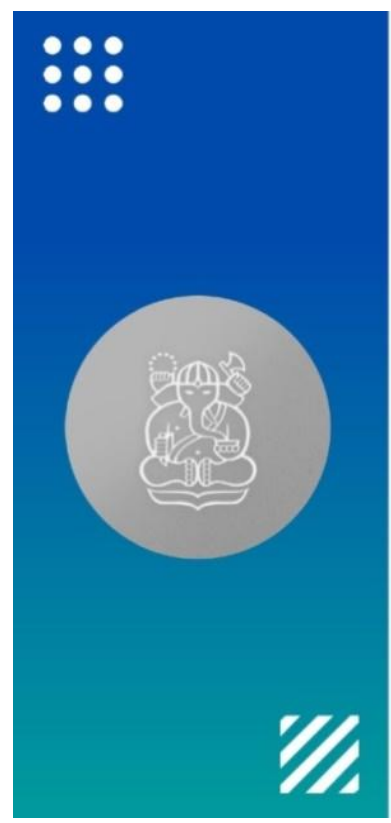

\section{CERTIFICATE \\ OF APPRECIATION \\ presented to}

\section{Dr. Wiwiek M. Daryanto}

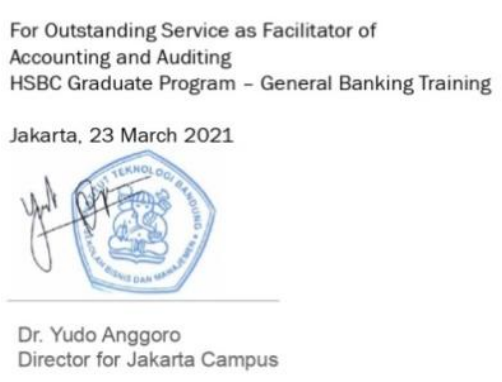

Fig. 4. Certificate as a facilitator (Source: Sekolah Bisnis dan Manajemen-Institut Teknologi Bandung (SBM-ITB), 2021)

\section{Conclusion}

Based on the discussion above, Audit, Accounting, and Finance training can help companies realize their goals. Through understanding of financial accounting, cost classification, and auditing, employees of PT HSBC Jakarta, Indonesia can understand the basic concepts of financial statements; financial statement analysis techniques and their application in the company; understand the function of auditing; as well as doing strategic planning in accordance to the company budget. In addition, this training can also improve the competence and productivity of the Human Resources (HR) of PT HSBC, Jakarta, Indonesia, which in turn will also increase the competitiveness of the PT HSBC, Jakarta, Indonesia. 


\section{Recommendation}

Given the great benefits of Audit, Accounting, and Finance training activities in improving the performance of company employees, it is necessary to conduct them regularly. And can be done with a longer duration.

\section{Acknowledgement}

The Audit, Accounting, and Finance training was supported by PT HSBC, Jakarta, Indonesia, and facilitated by Sekolah Bisnis dan Manajemen, Institut Teknologi Bandung (SBM-ITB). This training aimed to accelerate the performance of PT HSBC, Jakarta, Indonesia's employees. The author thanks the head of human resource of PT HSBC, Jakarta, Indonesia. The author also gratefully thanks Dr. Yudo Anggoro as a director of Sekolah Bisnis dan Manajemen, Institut Teknologi Bandung (SBM-ITB) for giving the opportunity to undertake The Audit, Accounting, and Finance training as one of the speakers. Not to mention, for all the staffs who directly and indirectly help running the training, the author thank them all.

\section{References}

Agoes, S. (2004), Auditing (Pemeriksaan Akuntan) oleh Kantor Akuntan. Publik: Edisi Ketiga, Jakarta: Fakultas Ekonomi Universitas Indonesia.

Anthony, R.N; Reece, J.S; and Hertenstein, J.H. (2011). Accounting: Text dan Case, Edition13. Irwin, Chicago.

Arens, A.A; Randal, J. E; dan Mark, SB. (2015). Auditing dan Jasa Assurance Pendekatan Terintegrasi. Jilid 1. Ed 5. Jakarta: Erlangga.

Bustami, B and Nurlela. (2010). Akuntansi Biaya. Edisi kedua. Jakarta: Mitra Wacana Media. Kasmir. (2016). Analisis Laporan Keuangan. Jakarta: Raja Grafindo Persada.

Mulyadi, (2002). Auditing. Edisi ke-6, Salemba Empat: Jakarta.

Mulyadi. (2010). Sistem Akuntansi. Edisi ke-3. Salemba Empat: Jakarta.

Purwaji A., Wibowo, Murtanto .H. (2016). Pengantar Akuntans 1. Edisi ke-2, Salemba Empat: Jakarta. 